\title{
Peranan Digital Marketing Bagi Usaha Mikro, Kecil, Dan Menengah (UMKM) Desa Tales Kabupaten Kediri
}

\author{
Juli Sulaksono' ${ }^{1}$ Nizar Zakaria ${ }^{2}$, \\ ${ }^{1}$ Ilmu Teknik, Universitas Udayana Bali \\ ${ }^{2}$ Teknik Informatika, Fakultas Teknik, Universitas Wahidiyah Kediri \\ E-mail: 1jsulaksono@gmail.com, 22zakaria_neezar@yahoo.co.id
}

\begin{abstract}
Abstrak-Digital marketing adalah kegiatan promosi dan pencarian pasar melalui media digital secara online dengan memanfaatkan berbagai sarana misalnya jejaring sosial. Tujuan dari penelitian ini adalah untuk meningkatkan pengetahuan dan keterampilan tentang pemasaran digital, terutama media sosial, bagi para pelaku bisnis Usaha Kecil dan Menengah (UKM) untuk meningkatkan penjualan dan laba mereka. Dihadiri oleh peserta UMKM Kirana Desa Tales, metode yang digunakan dalam kegiatan ini adalah; pertama, penjelasan menggunakan slide power point dan proyektor LCD; kedua, berbagi pengalaman dan diskusi; dan terakhir, praktik langsung membuat akun media sosial (Facebook dan Instagram) dan cara membuatnya menarik bagi pembeli (gambar, kata-kata, cerita, dll). Hasilnya menunjukkan bebarapa pelaku usaha secara aktif menggunakan media sosial sebagai alat promosi mereka dan mereka belum memisahkan akun toko online mereka dengan akun pribadi mereka, beberapa orang lain menggunakannya sesekali, dan sisanya peserta tidak pernah menggunakan pemasaran media sosial karena kurangnya teknologi ketrampilan. Semua peserta menunjukkan minat besar untuk menggunakan pemasaran media sosial secara terus menerus.
\end{abstract}

Kata Kunci-Digital Marketing, UMKM, Social Media

\begin{abstract}
Digital marketing is a promotional activity and market search through digital media online by utilizing various means such as social networking. The purpose of this research is to increase knowledge and skills about digital marketing, especially social media, for Small and Medium Business (SME) business people to increase their sales and profits. Attended by UMKM participants Kirana Desa Tales, the methods used in this activity were; first, an explanation of using a power point slide and LCD projector; second, sharing experiences and discussions; and finally, the direct practice of creating social media accounts (Facebook and Instagram) and how to make them attractive to buyers (pictures, words, stories, etc.). The results show some businesses actively use social media as a promotional tool and they have not separated their online store accounts from their personal accounts, some others use them occasionally, and the rest of the participants never use social media marketing due to lack of skills technology. All participants showed great interest in using social media marketing continuously
\end{abstract}

Keywords-Digital Marketing, UMKM, Social Media

\section{PENDAHULUAN}

Dunia digital diprediksi akan menjadi poin krusial bagi seluruh aktivitas manusia, termasuk aktivitas bisnis. Beberapa indikator yang bisa digunakan saat ini antara lain naiknya pengeluaran iklan digital, pertumbuhan kepemilikan smartphone yang menyediakan kemudahan akses internet, perbaikan infrastruktur telekomunikasi dalam rangka peningkatan kualitas akses data, serta diluncur- kannya layanan 4G. Menurut data Facebook, 74\% pengguna internet di Indonesia menggunakan perangkat mobile (Utomo, 2016). 
Pesatnya perkembangan teknologi, dunia digital dan internet tentu juga berimbas pada dunia pemasaran. Tren pemasaran di dunia beralih dari yang semula konvensional (offline) menjadi digital (online). Strategi digital marketing ini lebih prospektif karena memungkinkan para calon pelanggan potensial untuk memperoleh segala macam informasi mengenai produk dan bertransaksi melalui internet. Digital marketing adalah kegiatan promosi dan pencarian pasar melalui media digital secara online dengan memanfaatkan berbagai sarana misalnya jejaring sosial. Dunia maya kini tak lagi hanya mampu menghubungkan orang dengan perangkat, namun juga orang dengan orang lain di seluruh penjuru dunia.

Digital marketing yang biasanya terdiri dari pemasaran interaktif dan terpadu memudahkan interaksi antara produsen, perantara pasar, dan calon konsumen. Di satu sisi, digital marketing memudahkan pebisnis memantau dan menyediakan segala kebutuhan dan keinginan calon konsumen, di sisi lain calon konsumen juga bisa mencari dan mendapatkan informasi produk hanya dengan cara menjelajah dunia maya sehingga mempermudah proses pencariannya. Pembeli kini semakin mandiri dalam membuat keputusan pembelian berdasarkan hasil pencariannya. Digital marketing dapat menjangkau seluruh masyarakat di manapun mereka berada tanpa ada lagi batasan geografis ataupun waktu.

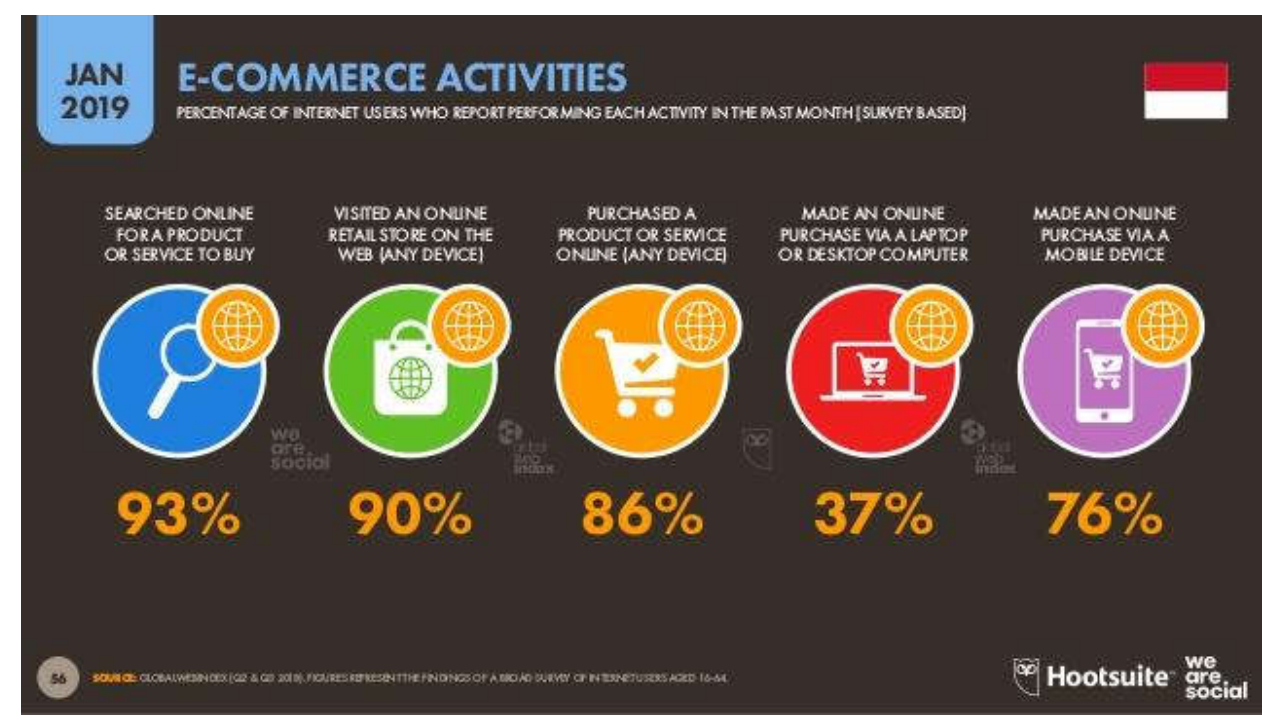

Gambar 1 Aktivitas Belanja Online

Sumber: https://www.slideshare.net/DataReportal/digital-2019-indonesia-january-2019-

Gambar di atas menjelaskan bahwa terhitung sampai Januari 2019, sebanyak 93\% pengguna internet di Indonesia melakukan pencarian barang atau jasa secara online, 90\% pengguna mengunjungi toko online dengan berbagai perangkat, $86 \%$ pengguna melakukan transaksi online dari berbagai perangkat (laptop dan mobile), 37\% pengguna melakukan transaksi melalui PC atau laptop, dan $76 \%$ pengguna melakukan transaksi online melalui perangkat smartphone. Dari penjelasan diatas menyiratkan bahwa potensi belanja online sudah cukup berkembang di Indonesia yang harus diimbangi dengan pemasaran secara digital pula oleh pelaku usaha.

Pengguna dalam melakukan pemasaran secara online yaitu dengan media sosia atau jejaring sosial. Jejaring sosial yang tersedia terkadang memiliki karakteristik yang berbeda. Ada yang sifatnya untuk menjalin pertemanan seperti Facebook, Instagram, Line, ada pula yang khusus untuk mencari dan membangun relasi seperti yang ditawarkan Linkedin. Tersedia pula media yang lebih pribadi seperti e-mail (electronic mail). Dari berbagai macam platform yang disampaikan di atas, pelaku usaha juga dapat memanfaatkan media situs pribadi.

Data yang dilansir oleh We are Social, sebuah agensi digital marketing di Amerika, menyebutkan bahwa platform media sosial yang paling banyak digunakan di Indonesia per Januari 2017 adalah Youtube (49\%) dan oleh Facebook (48\%). Posisi selanjutnya ditempati oleh Instagram 
(39\%), Twitter (38\%), Whatsapp (38\%), dan Google (36\%). Sisanya ditempati secara berurutan oleh FB Messenger, Line, Linkedin, BBM, Pinterest, dan Wechat (Kemp, 2017).

Sri Widowati, Country Head Facebook Indonesia, menyampaikan bahwa pengguna Facebook di Indonesia membuka halaman Faceboook milik mereka rata-rata 80 kali sehari (Utomo, 2016). Ia juga mengungkap data bahwa sebanyak $45 \%$ pengguna internet di Indonesia lebih suka berbelanja secara online. Angka ini diperkirakan akan terus meningkat seiring dengan pertumbuhan pengguna internet di Indonesia. Hal ini mencerminkan perilaku masyarakat Indonesia yang semakin mengarah ke gaya hidup digital. Namun peluang ini sepertinya tidak diikuti oleh perubahan perspektif mayoritas perusahaan dan individu yang terlibat dalam dunia digital marketing. Meski perusahaan besar, kecil, maupun individu kini sudah mulai menggunakan digital dan media sosial sebagai salah satu alat berpromosi atau mendekatkan diri kepada konsumen, namun sayangnya jumlahnya masih sangat terbatas. Pemanfaatan pemasaran melalui media digital (digital marketing) masih belum maksimal jika dibandingkan dengan pertumbuhan jumlah pengguna internet yang drastis.

Berdasarkan hasil riset McKinsey, baru sekitar 30\% usaha di Indonesia yang menggunakan instrumen digital dalam mengembangkan usahanya (Supriadi, http://www.marketing.co.id, 2016). Melihat hal ini, dapat kita simpulkan bahwa potensi digital marketing di Indonesia masih sangat besar. Usaha Mikro, Kecil dan Menengah (UMKM) memiliki peran penting dalam laju ekonomi Indonesia terutama dalam penciptaan lapangan kerja dan pemberdayaan rumah tangga yang mendukung pendapatan rumah tangga. Keberadaan UMKM diharapkan mampu memacu perekonomian di tengah perlambatan ekonomi yang terjadi saat ini. Pemanfaatan konsep pemasaran berbasis teknologi digital (digital marketing) memberikan harapan bagi UMKM untuk berkembang menjadi pusat kekuatan ekonomi.

Era digital memang tidak mungkin untuk dihindari. Pakar pemasaran Yuswohadi mengungkap- kan bahwa jika ingin bertahan, maka pelaku UMKM harus mampu memaksimalkan manfaat perkembangan digital (Maulana, 2017). Perkembangan teknologi digital memungkinkan para pelaku UMKM untuk memasarkan produknya secara online dan melakukan transaksi melalui sistem perbankan secara online pula. Media sosial merupakan suatusarana digital marketing yang paling mudah untuk dimanfaatkan. Sebelum sebuah usaha memiliki situs, tidak jarang kita menemukan terutama di pasar seperti Indonesia bahwa mereka telah memulai memasu- ki ranah dunia maya melalui media sosial. Hal ini dapat menjadi stimulan perkembangan kewirausahawanan dan keberlangsungan UMKM. Selain biaya yang murah dan tidak perlunya keahlian khusus dalam melakukan inisiasi awal, media sosial dianggap mampu untuk secara langsung meraih (engage) calon konsumen. Oleh karena itu tidak heran bahwa pelaku usaha justru lebih menitikberatkan peman- faatan media sosial dibanding dengan pengembangan sebuah situs. Para pelaku UMKM tersebut terhadang kendala masih minimnya pengetahuan terhadap digital marketing dan electronic commerce (e-commerce). Potensi pemanfaatan digital marketing ini mengharuskan masyarakat untuk melek teknologi, oleh karena itu diperlukan sosialisasi dan pelatihan penggunaan teknologi informasi dan komunikasi ini. Kegiatan pengabdian masyarakat mengenai pemanfaatan digital marketing ini diharapkan dapat memberikan pengetahuan dan pemahaman serta dapat menginspirasi pelaku UMKM dalam memanfaatkan teknologi internet dan jejaring sosial sebagai alat untuk menjalankan bisnisnya.

Penulis tertarik untuk mengkaji sejauh mana pemanfaatan digital marketing yang telah dilakukan oleh pelaku UMKM di Desa Tales Kabupaten Kediri, penyusun proposal mempunyai ide untuk menyeleng- garakan kegiatan pengabdian masyarakat bertema "Pemanfaatan Digital Marketing bagi Usaha Mikro, Kecil, dan Menengah (UMKM) di Desa Tales Kabupaten Kediri 


\section{METODE PENELITIAN}

Metodologi dari penelitian ini dibagi dalam desain penelitian dan subyek penelitian, metode pengumpulan data dan metode analisis data.

1. Desain Penelitian dan Subyek Penelitian Penelitian ini merupakan penelitian deskriptif observasional pada UMKM Desa Tales Kabupaten Kediri menggunakan metode triangulasi yang menggabungkan metode wawancara terstruktur, wawancara mendalam dan observasi terhadap Ibu-Ibu PKK dan media sosial yang digunakan. Subyek dalam penelitian ini adalah pengrajin yang dipilih secara purposive sampling. Subyek dipilih sesuai dengan kriteria:

a) merupakan pengrajin,

b) pernah menggunakan media sosial dalam komunikasi usahanya, bersedia menjadi subyek penelitian. Total subyek yang direkrut dalam penelitian sebanyak 15 Orang.

2. Metode Pengumpulan Data Penelitian ini menggunakan data primer yang diperoleh berdasarkan wawancara terstruktur dan wawancara mendalam kepada pengrajin. Data yang diperoleh meliputi data karakteristik umum, data penggunaan sosial media dalam UMKM, termasuk tujuan, manfaat dan hambatan yang dihadapi. Data dilengkapi dengan hasil observasi peneliti terhadap ibiibu PKK dan media sosial yang digunakan.

Analisis Data Data yang diperoleh dianalisis menggunakan statistik deskriptif dan analisis kualitatif.Sub Bab.

\section{PENGACUAN PUSTAKA}

\section{A. Digital Marketing}

Teknologi digital telah mengubah cara manusia dalam berkomu- nikasi, bertindak, dan mengambil keputusan. Aktivitas pemasaran pun tak lepas dari pengaruh teknologi digital. Istilah pemasaran berbasis digital (digital marketing) telah mengalami evolusi dari awalnya kegiatan pemasaran barang dan jasa yang menggunakan saluran digital hingga pengertian yang lebih luas yaitu proses memperoleh konsumen, membangun preferensi konsumen, mempromosikan merek, memelihara konsumen, danmeningkatkan penjualan.

Konsep digital marketing berasal dari internet dan mesin pencari (search engines) pada situs. Ketika penggunaan internet meledak di tahun 2001, pasar didominasi oleh Google dan Yahoo sebagai search engine optimization (SEO). Definisi digital marketing menurut American Marketing Association (AMA) adalah aktivitas, institusi, dan proses yang difasilitasi oleh teknologi digital dalam menciptakan, mengomunikasikan, dan menyampaikan nilai-nilai kepada konsumen dan pihak yang berke- pentingan lainnya (Kannan \& Hongshuang, 2016).

Digital marketing didefinisikan juga sebagai kegiatan pemasaran yang menggunakan media berbasis internet (Wardhana, 2015).Internet adalah alat yang cukup berpengaruh untuk bisnis. Roger dalam Rahardjo (2011) me- ngungkapkan ciri-ciri internet adalah sebagai berikut:

a. Interactivity, kemampuan perang- kat teknologi memfasilitasi komu- nikasi antar individu seperti bertatap muka langsung. Komuni- kasi terjalin sangat interaktif sehingga para partisipan bisa berkomunikasi dengan lebih akurat, efektif, dan memuaskan.

b. Demassification, pesan dapat dipertukarkan kepada partisipan yang terlibat dalam jumlah 
besar.

c. Asynchronous, teknologi komuni- kasi mempunyai kemampuan untuk mengirimkan dan menerima pesan pada waktu yang dikehendaki setiap peserta.

Media sosial memungkinkan pelaku usaha untuk mencapai konsumen dan membangun hubungan yang lebih personal. Zhu dan Chen (2015) membagi media sosial ke dalam dua kelompok sesuai dengan sifat dasar koneksi dan interaksi:

1. Profile-based, yaitu media sosial berdasarkan profil yang fokus kepada anggota individu. Media sosial kelompok ini mendorong koneksi yang terjadi karena individu tertarik kepada pengguna media sosial tersebut (e.g. Facebook, Twitter, WhatsApp).

2. Content-based, yaitu media sosial yang fokus kepada konten, diskusi, dan komentar terhadap konten yang ditampilkan. Tujuan utamaya adalah menghubungkan individu dengan suatu konten yang disediakan oleh profil tertentu karena individu tersebut menyukainya (e.g. Youtube, Instagram, Pinterest).

Media sosial telah membuka pintu bagi pelaku usaha untuk berkomunikasi dengan jutaan orang mengenai produk mereka dan telah menciptakan peluang pemasaran baru.

\section{b. Pemanfaatan Digital Marketing oleh Pelaku UMKM}

Media sosial berpotensi untuk membantu pelaku UMKM dalam memasarkan produknya (Stelzner, 2012). Aplikasi media sosial tersedia mulai dari pesan instan hingga situs jejaring sosial yang menawarkan pengguna untuk berinteraksi, berhubungan, dan berkomunikasi satu sama lain. Aplikasi-aplikasi ini bermaksud untuk menginisiasi dan mengedarkan informasi online tentang pengalaman pengguna dalam mengonsumsi produk atau merek, dengan tujuan utama meraih (engage) masyarakat.

Dalam konteks bisnis, people engagement dapat mengarah kepada penciptaan profit.

Wardhana (2015) menemukan bahwa strategi digital marketing berpengaruh hingga 78\% terhadap keunggulan bersaing UMKM dalam memasarkan produknya. Strategi tersebut terdiri dari:

1. Ketersediaan informasi produk dan panduan produk;

2. Ketersediaan gambar-gambar seperti foto atau ilustrasi produk;

3. Ketersediaan video yang mampu memvisualisasikan produk atau menampilkan presentasi pendu- kung;

4. Ketersediaan lampiran dokumen- dokumen yang berisi informasi dalam berbagai format;

5. Ketersediaan komunikasi online dengan pengusaha;

6. Ketersediaan alat transaksi dan variasi media pembayaran;

7. Ketersediaan bantuan dan layanan konsumen;

8. Ketersediaan dukungan opini online;

9. Ketersediaan tampilan testimonial;

10. Ketersediaan catatan pengunjung;

11. Ketersediaan penawaran khusus;

12. Ketersediaan sajian informasi terbaru melalui SMS-blog;

13. Kemudahan pencarian produk;

14. Kemampuan menciptakan visibilitas dan kesadaran merek;

15. Kemampuan mengidentifikasi dan menarik pelanggan baru;

16. Kemampuan penguatan citra merek yang diterima oleh konsumen.

c. Pemanfaatan digital marketing memiliki beberapa keunggulan, antara lain:

1. Target bisa diatur sesuai demografi, domisili, gaya hidup, dan bahkan kebiasaan;

2. Hasil cepat terlihat sehingga

3. pemasar dapat melakukan tindakan koreksi atau perubahan apabila dirasa ada yang tidak 
sesuai;

4. Biaya jauh lebih murah daripada pemasaran konvensional;

5. Jangkauan lebih luas karena tidak terbatas geografis;

6. Dapat diakses kapanpun tidak terbatas waktu;

7. Hasil dapat diukur, misalnya jumlah

pengunjung situs, jumlah konsumen yang melakukan pembelian online;

8. Kampanya bisa dipersonalisasi;

9. Bisa melakukan engagement atau meraih konsumen karena komunikasi terjadi secara langsung dan dua arah sehingga pelaku usaha membina relasi dan menumbuhkan epercayaan konsumen.

Di sisi lain, digital marketing pun memiliki kelemahan, di antaranya:

1. Mudah ditiru oleh pesaing;

2. Dapat disalahgunakan oleh pihak- pihak tidak bertanggung jawab;

3. Reputasi menjadi tidak baik ketika ada respon negatif;

4. Belum semua orang menggunakan teknologi internet/digital.

Sosialisasi strategi digital marketing dalam bentuk peman- faatan media sosial sangatlah penting karena dapat memberi pengetahuan kepada para pelaku UMKM mengenai cara maupun tahapan dalam memperluas jaringan konsumen melalui pemanfaatan media sosial dalam memasarkan produknya sehingga dapat meningkatkan keunggulan bersaing bagi UMKM itu sendiri.

\section{HASIL DAN PEMBAHASAN}

\section{Karakteristik UMKM}

Subyek dalam penelitian ini adalah pelaku UMKM di Desa Tales, yang memproduksi berbagai macam jenis barang serta makanan.

\section{Penggunaan Media Sosial pada UKM}

Ibu-Ibu PKK dalam penelitian ini, menggunakan media sosial sebagai media informasi dan komunikasi kegiatan usahanya. Rata-rata yang digunakan adalah, facebook dalam menampilkan profil perusahan. E-mail, dan WhatsApp (WA) dan Istagram (IG) untuk gambar-gambar produk. Hampir sebagian dari Ibu-Ibu PKK, menganggarkan dana sebesar Rp.100.000-250.000,- untuk membeli pulsa sebagai sarana dalam pengelolaan. media sosial sebagai informasi dan komunikasi usahanya. Bahkan mereka secara rutin selalu memperbaharui (update) informasi yang ditampilkan di media sosial setiap hari.

\section{Pengaruh Penggunaan Media Sosial Ibu-Ibu PKK}

Penggunaan media sosial bagi Ibu-Ibu PKK sangat bermanfaat antara lain adalah, sebagai sarana kontak langsung dengan pemesan, sebagai sarana untuk mempromosikan hasil karya industry rumahan, mendata keinginan konsumen, menyampaikan respon kepada masyarakat. Berikut data peserta UMKM Kirana dan sebagain besar adalah Ibu-Ibu PKK.

Tabel 2.1 Daftar Pelaku UMKM

\begin{tabular}{|c|c|c|}
\hline No. & Nama & Keterangan \\
\hline 1 & Ana Imroatus & Pelaku UMKM Kirana \\
\hline 2 & Anis Kristiana & Pelaku UMKM Kirana \\
\hline 3 & Bayu Fadilla & Pelaku UMKM Kirana \\
\hline
\end{tabular}




\begin{tabular}{|c|c|c|}
\hline 4 & Diana Safitri & Pelaku UMKM Kirana \\
\hline 5 & Dinda Agita & Pelaku UMKM Kirana \\
\hline 6 & Eka S. Wahyuni & Pelaku UMKM Kirana \\
\hline 7 & Erni Ningsih & Pelaku UMKM Kirana \\
\hline 8 & Ike Wijayanti & Pelaku UMKM Kirana \\
\hline 9 & Krismayanti & Pelaku UMKM Kirana \\
\hline 10 & Fajarwati & Pelaku UMKM Kirana \\
\hline 11 & Etin Muji & Pelaku UMKM Kirana \\
\hline 12 & Inda Lestari & Pelaku UMKM Kirana \\
\hline 13 & Miftahul Yanah & Pelaku UMKM Kirana \\
\hline 14 & Cicik Putri & Pelaku UMKM Kirana \\
\hline 15 & Nonik Adisti & Pelaku UMKM Kirana \\
\hline 16 & Hermin Cholifah & Pelaku UMKM Kirana \\
\hline 17 & Ika Ratna & Pelaku UMKM Kirana \\
\hline 18 & Neneng Kartika & Pelaku UMKM Kirana \\
\hline 19 & Eli Istimewa & Pelaku UMKM Kirana \\
\hline 20 & Puji rahayu & Pelaku UMKM Kirana \\
\hline
\end{tabular}

Dari 20 orang peserta, hanya beberapa orang yang telah menggunakna media social secar aktif untuk memasarkan produk mereka. Platform media social utama yang mereka gunakan adalah Facebook, Instagram, dan Whatsapp, karena platform ini yang paling familiar bagi mereka. Anggapan mereka penggunaan digital marketing cukup sulit, mereka juga tidak banyak transaksi actual yang terjadi dibandingkan dengan berjualan langsung. Sebanyak 8 orang peserta lainnya mereka sudah memanfaatkan media social untuk memasarkan produk mereka, sisanya mereka belum pernah menggunakan media social. Mereka tidak ingin mencoba karena ketidaktahuan bagaimana mengoperasikan teknologi tersebut.

Meski media social belum dimanfaatkan secara maksimal, tetapi para pelaku UMKM khususnya di Desa Tales ini telah menggunakan media digital lain untuk proses transaksi. Pada umumnya mereka menggunakan aplikasi pesan singkat seperti WhatsApp untuk bertukar pesan, promosi, dan bertransaksi, serta menggunakan transker elektronik untuk melakukan pembayaran.

\section{SIMPULAN}

Pengguna teklogi digital telah mempengaruhi segala aspek kehidupan dan kegiatan manusia, termasuk pemasaran. Pemasaran berbasis digital digunakan untuk mendapatkan konsumen, membangun preferensi mereka, promosi merek, memelihara konsumen, serta meningkatkan jumlah produk yang terjual dan pada akhirnya meningkatkan profit. Digital Marketing memungkinkan pembeli memperoleh seluruh informasi mengenai produk dan dapat melakukan transaksi jual beli melalui internet. Seperti halnya penjual, mereka juga dapat memantau, dan menyediakan kebutuhan serta keinginan calon pembeli tanpa batasan waktu dan geografis. 
Digital marketing merupakan komunikasi dua arah yang dapat menimbulkan awareness dan engagement masyarakat terhadap produk dan merek tertentu.

Perubahan perilaku pemasaran dari konevensional ke digital tidak diimbangi oleh keberadaan pelaku UMKM yang menggunakan digital marketing, padahal UMKM dipercaya mampu memacu perekonomian Indonesia. Pemanfaatan konsep pemasaran secara digital menjadi harapan bagi UMKM untuk berkembang menjadi pusat kekuatan ekonomi. UMKM dapat memanfaatkan teknologi digital khusunya media social sebagai sarana digital marketing. Selain biaya murah, dan tidak dibutuhkannya keahlian khusus dalam melakukan inisiasi awal, media social dianggap mampu untuk secara langsung meraih konsumen. Minimnya pengetahuan pelaku UMKM mengenai digital marketing menginspirasi tim pengabdian kepada masyarakat ini menjadi kendala bagi pelaku usaha dalam memasarkan produknya yang seriring berkembangnya zaman. Apabila para pelaku UMKM paham akan pentingnya teknologi digital, dalam hal ini digital marketing bagi usaha mereka, diharapkan mereka termotivasi untuk menggunakan digital marketing sebagai sarana promosi.

Dari penelitian ini, diperoleh wawasan bahwa sesungguhnya para pelaku UMKM tertarik untuk menggunakan digital marketing dan memanfaatkan media social secara optimal, namun mereka menghadapi beberapa kendala, seperti halnya kurangnya pemahaman tentang teknologi informasi. Pemahaman mereka tentang bagaimana memaksimalkan platform Facebook, Instagram, Marketplace sangat kurang, bagaimana menciptkan "postingan" yang menarik dan dapat mempengaruhi pembeli

\section{SARAN}

Saran dalam digital marketing dengan media social untuk pelaku UMKM yaitu:

1. Membuat akun media social untuk usaha dan akun pribadi, dibuat secara terpisah;

2. Membuat branding, dengan akun nama yang mudah diingat, mudah dihafal, menjelskan tentang produk yang dijual;

3. Posting foto produk secara berkala, dan pada jam dimana konsumen melihat postingan produk (prime time);

4. Posting produk sesuai dengan apa yang dijual;

5. Buatlah hastag atau tanda pagar untuk mencirikan usaha kita;

6. Sebisa mungkin utuk menjawab pertanyaan para konsumen.

\section{DAFTAR PUSTAKA}

[1] Kannan, P. K., \& Hongshuang, L. (2016).Digital Marketing: A Framework,Review and Research Agenda.International Journal of Research inMarketing .

[2] Wardhana, A. (2015). Strategi Digital Marketing dan Implikasinya pada Keunggulan Bersaing UKM di Indonesia.

[3] Stelzner, M. (2012, April). How Marketersare Using Social Media to Grow TheirBusiness. 